\title{
NORSK SPRÅK I MØTE MED ENGELSK
}

\author{
MARTIN SKJEKKELAND
}

Det er mange menneske i Noreg som er engstelege for at engelsk skal overta som bruksspråk på fleire område av det norske samfunnet, og dei trur at engelske ord vil fortrenga norske ord meir og meir. At slike tankar kjem opp, er ikkje så merkeleg. For dei aller fleste av oss er det heilt naturleg å ta i bruk ein del engelske ord når me skal fortelja om ei oppleving me har hatt. Sist sommar var me på cruise og blei også med på sightseeing i fleire byar. På denne reisa skaffa me oss iPphone og iPad. Dottera vår joina sist laurdag eit trendy "bad taste party", med boots og collegegenser som del av antrekket. Der digga alle discomusikk frå dei siste hitlistene. Maten var fast food, men også brownie og bagels.

At me låner ord frå andre språk, er ikkje noko nytt. Me har opp gjennom tidene tatt imot ord frå mange språk, og særleg frå latin, gresk, nedertysk, fransk og engelsk. Dei eldre importorda ser me lite til ettersom dei er så godt assimilerte i språket, dei er tilpassa det norske språksystemet. Døme på dette er ordet jern frå keltisk, kyrkje frå gresk, plante frå latin, snakke frå tysk, moderne frå fransk, konto frå italiensk, trålar frå engelsk, kjendis frå svensk, pulk frå samisk, sofa frå arabisk osv. Ser me på dei nyare importorda, så kjem dei fleste av dei frå engelsk, og mange av dei passar dårleg inn i norsk språkstruktur. Me skal sjå litt på korleis me møter dei engelske lånorda, men først nokre ord om dei eldre ordleverandørane våre.

Ei mengd abstrakte og akademiske ord har kome frå gresk og latin. Av dei ca. 13500 importorda i norsk kjem 4100 frå latin og 2100 frå gresk (jf. Sandøy, 2000). Frå latin har me fått ord som: kristen, prest, nonne, messe, kåpe, ofre, brev, plante osv. Ord med latinske ordstammar er: abdikasjon, attraksjon, depresjon, diktere, ekskludere, infiltrere, konferere, kollektiv, manuskript, mobilitet, normere, produsere, passivisere, reaksjon osv. Ordstammar frå gresk finn me i pedagog, autonom, demokrati, geograf, psykolog, telefon osv. 
Det er likevel det nedertyske språket som har påverka det norske språket aller mest. Dei mange nedertyske orda kom inn i norsk med hansakjøpmennene på 1300- og 1400-talet. Nye varer og nye handverk blei formidla av tyskarane. Hansaspråket sette merke på alt som var knytt til bylivet som utvikla seg på denne tida. Nedertyske ord i daglegspråket vårt er til dømes betale, bli, bukse, billeg, enkel, ekteskap, frukt, flink, frykte, handle, handverk, håpe, lukt, måte, plage, prate, pris, prøve, rente, reise, snakke, skrive, vandre og hundrevis andre (jf. Jahr 2000). Frå hollandsk fekk me på 1500-talet ord frå sjømannslivet: anker, bedding, dørk, dekk, fartøy, gast, kryssar, matros, peile, slingre, spleise osv. Mange faste utrykk i norsk kjem frå nedertysk: spott og spe, rubb og stubb, hulter til bulter, til punkt og prikke osv.

I dag kjem som nemnt dei fleste lånorda frå engelsk. Språket vårt er under press frå engelsk på to måtar: 1) det engelske språket tek gradvis over som bruksspråk på visse samfunnsområde (til dømes forsking og høgare undervisning) og 2) engelske ord tek plass i norsk daglegspråk. Nokre meiner at me gradvis får det som kan kallast "anglonorsk". Mange av dei engelske orda kjem til oss gjennom den teknologiske utviklinga, og særleg gjeld det datateknologien (jf. Guttu og Wangesteen, 2012). Likevel, mest synelege er alle engelske orda knytte til moderne kultur og livsstil, det gjeld musikk (hit, disco, breakdance osv.), klede og mote (jeans, duffelcoat, cityshorts osv.), mat og drikke (hot dog, burger, bagel, donut osv.) (jf. Graedler og Johansson, 2002). Ord frå engelsk tek plass i ungdomsspråket, og kjem også fram i annonsar, på reklameplakatar og butikkskilt: "Stonewashed jeans", "Levis Authorized Dealer", "Dahl's flytteconsultant", "Body Shop", "Jimmys Steakhouse", "Pick-up Burgerhouse" osv.

Innfor språkvitskapen skil ein mellom arveord på eine sida (dei orda som me ha hatt med oss frå så langt tilbake som me kan følgja språket) og lånord og framandord på den andre sida. Lånord og framandord blir med eit samleomgrep kalla importord. Lånord og framandord er ord som har komme inn i språket vårt $\mathrm{i}$ dei historiske periodane me har oversikt over. Om lag 30\% av orda i Bokmålsordboka og Nynorskordboka er importord. Ser me bort frå samansetningar og avleiingar, kan me rekna oss fram til at $44 \%$ av ordstammane eller grunnorda i til dømes Nynorskordboka er importerte i språket. Skiljet mellom framandord og lånord går på om ordet har fått ei form som gjer det veltilpassa språkleg. Eg har ovanfor gjeve døme på veltilpassa lånord frå nedertysk. Også blant dei engelske lånorda finst det slike tilpassa ord: stress, mobbing, harddisk, rafte, fotball, basket, digge, dress, krasje, strippe, sjekke, teit, dønn osv.

Problemet med engelsk er at dette språket forsyner oss med mange ord som ikkje lèt seg innpassa i norsk språkstruktur. Dei har ein framand skrivemåte og eit framandt bøyingsmønster. Dei stikk seg ut og uroar det norske systemet. I tillegg til døma ovanfor (musikk, mote osv.) kan ein nemna: facts, caps, display, image, coaching, iPhone, iPad, laptop, smiley, selfie osv. For mange slike ord prøver 
Språkrådet å finna norske "avløysarord". Nokre gonger lykkast dette bra. I dag er det ganske vanleg at folk både seier og skriv tilbakemelding (ikkje feedback), brettsegling (ikkje windsurfing), rullebrett (ikkje skateboard), idédugnad (ikkje brainstorming), marknadsføring (ikkje marketing), støtteark (ikkje handout), og minnepenn (ikkje memory stick). Men mange ord lever som nemnt vidare i si engelske form, til dømes deadline, headhunting, layout, smartphone, bodylotion, milkshake, smoothie o.a. Nokre gonger kjem det nylaga norske avløysarordet for seint til å ta over for det etablerte engelske. Eit døme er carport (ikkje bilstø som blei foreslått av Språkrådet). Avløysarordet utanskjcersindustri har heller ikkje utkonkurrert offshoreindustri.

Dersom me ikkje lykkast med å finna eit nytt norsk ord til erstatning for det for det engelske, kan me tilpassa framandordet til norsk skrivemåte. Dette blir kalla "norvagisering". I 1996 innførte Språkrådet norsk alternativ skrivemåte i 49 framandord, og gradvis har det kome fleire til. Me kan nå skriva: gaid eller guide, fait eller fight, finisj eller finish, innputt eller input, keitering eller catering, sjarter eller charter, sjåk eller choke, sørvis eller service. Vedtaket om innføring av norsk alternativ skrivemåte i slike ord førte til ein heftig mediedebatt med over 500 avisinnlegg. Mange meinte at me burde halda på ein internasjonal skivemåte $i$ framandorda då dette er med på å effektivisera kontakten med omverda, og også med på å gjera oss merksame på dei kulturhistoriske samanhengane me er ein del av.

Blant språkvitarar her i landet er det ikkje så mykje frykt for dei engelske orda som kjem til oss. Norsk språk er sterkt nok til å ta imot alle desse orda, blir det hevda. Nei, det store trugsmålet frå engelsk er at dette språket skal overta som hovudspråk på visse bruksområde (domene) i samfunnet.

Regjeringa Stoltenberg la 27. juni 2008 fram Språkmeldinga (St.meld. 35. 20072008). Her slår ein fast at "det er domenetap, full overgang til engelsk innanfor eit språkleg bruks- eller funksjonsområde, som representerer den store faren for norsk språk i dag.” Og dette er ein reell fare! Bruk av engelsk grip om seg meir og meir. Mest utsett er næringslivet og undervisning og forsking på universiteta våre. Ser ein til dømes på stillingsannonsane i Aftenposten, vil ein oppdaga at om lag ein fjerdedel er skrivne på engelsk.

I mange land i Europa breier engelsk seg som undervisningsspråk med stor fart. I botnen for denne utviklinga ligg Bologna-avtalen, ein samarbeidsavtale inngått i 1999 mellom dei fleste europeiske landa. Målet med denne avtalen var å skapa eitt felles europeisk område for høgare utdanning innan 2010. Her er det at det engelske språket kjem inn. Mange innan akademia, og også politikarar, har meint at dersom me skal få til internasjonalisering, må me tilby undervisning på engelsk. Og vidare blir det sagt: Norske forskarar må kunna kommunisera med europeiske fagmiljø på engelsk.

I stortingsvedtaket frå 2009 blei det understreka at det overordna målet for språkpolitikken må vera å sikra det norske språkets posisjon som eit fullverdig, sam- 
funnsberande skriftspråk i Noreg, og vidare: "Dette fordrar eit kontinuerleg arbeid over eit breitt felt med sikte på å styrkja og utvikla norsk som eit rikt og funksjonelt bruks- og kulturspråk og som uomstridt nasjonalspråk og hovudspråk i Noreg." Stortinget framheva at det var viktig å bevara norsk både som bruksspråk og som fagspråk, og at ein må kjempa for å halda i hevd norsk fagspråk parallelt med engelsk innanfor undervisning og forsking, og i næringslivet. I samsvar med meininga til stortingsfleirtalet gjorde fleire norske akademiske institusjonar i 2010 vedtak om ein ny intern språkpolitikk der norsk språk skulle styrkast innan forsking og undervisning.

I dag ser ein likevel at dei vedtekne retningslinjene frå 2010 berre i liten grad er følgde opp i praksis ved universiteta. Bruken av engelsk har auka råderommet sitt. Det blir stadig undervist meir på engelsk ved norske universitet og høgskular (Språknytt 3/2014). På alle norske universitet møter ein i dag mange utvekslingsstudentar frå andre land. Når ein forelesar kjem inn i eit auditorium med 50 studentar, er det kanskje 6-7 utanlandsstudentar der. For læraren kan det då mest kjennast uhøfleg å snakka norsk. "Dei norske i auditoriet forstår jo alle engelsk," Terskelen er såleis låg for at jamvel norskspråklege kurs av praktiske grunnar blir underviste på engelsk! Ein del fag ved norske universitet er i dag fullt ut engelskspråklege.

I vitskaplege publikasjonar er norsk i dag knapt i bruk innafor teknologi og naturfag. Innafor humaniora og samfunnsvitskap gjekk bruken av norsk i vitskapleg publikasjonar ned frå 60 til 50\% i tidrommet 2005-2011. Når det gjeld doktoravhandlingar, er prosentdelen skriven på norsk endå lågare. Innan humaniora ligg norsk-prosentdelen her på ca. 30, i samfunnsvitskap på vel 20 (tala gjeld dei tre største universiteta). Også når det gjeld masteroppgåver, er norsk på vikande front. Bruken av norsk språk gjekk her ned frå 82\% i 1986 til 60\% i 2011, alle fag sedde under eitt (jf. Gregersen, 2014). Den auka bruken av engelsk har få gode argument å visa til når ein veit at $90 \%$ av dei som avsluttar høgare utdanning her i landet, får det framtidige arbeidet sitt i norske fagmiljø!

Me ser av dei nemnde tala at det trengst ei bevisstgjering om styrking av norsk som fagspråk parallelt med engelsk. Men samtidig som ein kjempar ein kamp for norsk som bruksspråk og fagspråk, er det viktig å sjå etter at norsk språk ikkje smuldrar opp innanfrå ved at engelske ord med framandt uttale- og skrivemønster får prega det norske ordforrådet og det norske språksystemet.

\section{Litteratur}

Graedler, A.-L. og S. Johansson. 2002. Rocka, Hipt, og Snacksy. Om engelsk i norsk språk og samfunn. Kristiansand: Høyskoleforlaget.

Gregersen, F. (red.). 2014. "Hvor parallelt. Om parallellspråklighet på Nordens universitet". TemaNord, Nordisk ministerråd. http://norden.diva-portal.org/smash/get/diva2:730884/FULL TEXT01.pdf 
Guttu, T. og B. Wangensteen. (red). 2012. Nyord i norsk. Oslo: Kunnskapsforlaget.

Jahr, E.H. (red.). 2000. Språkkontakt - Innverknaden frå nedertysk på andre nordeuropeiske språk. København: Nordisk ministerråd.

Norsk $i$ hundre! - Norsk som nasjonalspråk i globaliseringens tidsalder. Et forslag til strategi 2005. Oslo: Språkrådet.

Sandøy, H. 2000. Lånte fjører eller bunad? Om importord $i$ norsk. Oslo: Cappelen akademisk Forlag.

Simonsen, D.F. 2014. "Undervisning på engelsk - sett fra kateteret”. Språknytt 3/2014. http://www.sprakradet.no/Vi-og-vart/Publikasjoner/Spraaknytt/spraknytt-2014/Spraknytt-32 014/Undervisning-pa-engelsk--sett-fra-kateteret/ 
